\title{
The Big 12: The Most Important Character Strengths for Military Officers
}

\author{
By Ole Boe* \\ Henning Bang ${ }^{\dagger}$
}

\begin{abstract}
The Norwegian Military Academy's main role is to educate future military leaders for the Norwegian Army. After graduating from the Norwegian Military Academy, these leaders will most likely have to deal with a great deal of responsibility and to cope with challenging and difficult situations. Leadership in these situations will demand a high degree of both intellect and character. Systematic research on the specific character strengths that are crucial to possess for military officers to succeed as military leaders is lacking. The purpose of this study is to investigate the experienced military officer's perception of which character strengths are seen as the most important for military officers in order to succeed as military leaders. A second aim was to investigate if there was any degree of consistency between the character strengths chosen in the present study and those chosen in previous studies. Method: A group of participants consisting of 21 military officers with an average of 10.3 years of active service in the Norwegian Armed Forces took part in the study. The officers were students of the Norwegian Military Academy when the present study was conducted. A list of 24 character strengths was given. The participants were then requested to judge each character's strength separately based on their subjective perception of the character's strengths importance for military officers. As a result 13 character strengths were selected as the most important for military officers and their leadership. These were in ranked order: leadership, teamwork, open-mindedness, integrity, persistence, bravery, curiosity, love of learning, social intelligence, fairness, perspective, creativity and self-regulation. Conclusions: The results from the present study are consistent and thus corroborate well with findings from the four previous studies conducted at the Norwegian Military Academy. In these four previous studies, 12 of the same 12 character strengths were also chosen as the most important ones for military officers. There thus seems to be a very strong consensus among military officers regarding which character strengths that are seen as important for military officers.
\end{abstract}

Keywords: Character, Character strengths, Education, Military.

\section{Introduction}

Norwegian military officers will most certainly face dangerous situations known as "in extremis" leadership (Kolditz 2010) or the unforeseen (Torgersen et al. 2013) when solving their assigned missions. The Norwegian Military Academy (NMA) thus aims at selecting the best possible officer candidates for

\footnotetext{
* Associate Professor, Norwegian Military Academy, Norway.

${ }^{\dagger}$ Associate Professor, University of Oslo, Norway.
} 
the entrance into its educational programs. The selection process uses a variety of measures, such as IQ tests, personality tests, an interview, and prognoses of leadership and academic potential based upon previous performance. Still, it is hard to predict among the selected officer candidates who will be the most successful in his or her job as an officer. Character strengths are seen as important in building resilience in military officers so that they will be able to cope with dangerous and difficult situations (Boe 2016).

Personality traits definitely have a use when it comes to predicting job performance in many occupations (Furnham \& Fudge 2008, Schmidt and Hunter 1998). On the other hand, their use has been found to be somewhat limited for the so-called high-risk occupations (Barrick and Mount 1991, Picano and Roland 2012). The military is a typical high-risk organisation and in personnel serving in these organisations are said to have high-risk occupations. A high-risk occupation means an occupation where personnel may have to face unpredictable, difficult and stressful situations in their daily work. Said differently, the personnel must be able to handle situations that occur suddenly and surprisingly, with an unknown content, where outcomes of actions characterized by a low degree of predictability (i.e. the unforeseen) (Torgersen et al. 2013). The Norwegian Chief of Defence (Forsvaret 2012:11) has stated: "[Military leadership] is about doing the uncomfortable and being able to cope with it, overcoming powerlessness, and avoiding emotional breakdown. Military leadership demands a robustness in order to think clearly and effectively and to cope with one's feelings when facing complex and difficult situations"(authors' translation). Character strengths will contribute to creating this robustness. However, very little research has focused upon which character strengths are the most important for military officers.

\section{The Use of Character Strengths and Personality Traits in Selection}

Previous attempts to identify suitable characters and to predict performance in the military and in other high-risk organizations have usually been based upon measurements of personality (Elsass et al. 2001, Picano and Roland, 2012, Picano et al. 2006). One challenge with this is that personality is about differences between individuals when it comes to how one reacts to circumstances, while character is about the values that govern the actions and behavior (Biswas-Diener et al. 2011).

A question often posed is who will succeed in leading others. It has been found that openness is the best predictor of maximum performance among military personnel (Ployhart et al. 2001). Sosik and Megerian (1999) investigated the emotional intelligence and performance of leaders. They found that the correlations between the aspects of emotional intelligence, the leader's behaviour, and the resulting performance varied as a function of the leader's level of self-awareness. In a meta-analysis conducted by Picano et al. (2002) it was found that personality and general mental ability could account for only $15 \%$ of the variance in ratings of the suitability of applicants for high-risk occupations. 80 personality and intelligence measures were examined in this 
meta-analysis. On the other hand, character strengths can be developed through increased vigilance and effort, and is a phenomenon that exists along with objectives, interests and values (Biswas-Diener et al. 2011). They also state that character strengths are specific phenomenon that co-exists with goals, interests, and values. Research at the NMA during a combat fatigue course revealed that cadets lost both their situation awareness and their ability to focus on certain missions while being sleep deprived (Matthews et al. 2011, Matthews et al. 2007). Avoiding this will be important for a military officer during a mission. Working on developing certain character strengths may be a way of countering these types of incidents. It has been shown that having character and commitment has proved to be successful factors during the selection of the Special Forces units (Boe 2011, Boe et al. 2011). However, which character strengths that are the most important ones for military officers is still a work in progress. The aim of this paper is therefore to investigate which character strengths military officers consider to be the most important for a military officer. A second aim is to investigate if the selected character strengths in the present study are consistent with previous studies on important character strengths for military officers (Boe and Bang n.d. a, n.d. b, Boe et al. 2015b, 2015c).

Gayton and Kehoe (2015b) asked applicants to the Australian Army Special Forces to rank themselves on 24 character strengths at the start of their selection process. The most frequently assigned character strength was integrity followed by team worker, persistence and love of learning. Successful applicants assigned a top-four rank to teamwork significantly more often than unsuccessful applicants did. The likelihood of passing when teamwork was highly ranked was 2.6 times greater than without team worker listed in the top ranks. Self-ratings of hardiness revealed no discernible differences between successful and unsuccessful applicants, either alone or in combination with the team worker rankings. These results were largely consistent with the results of a previous study (Gayton and Kehoe 2015a) with a cohort of applicants for a different Australian Special Forces unit. In this previous study, applicants were asked to rank themselves on 24 character strengths at the beginning of their selection process. The successful applicants assigned their top ranks to the three character strengths: teamwork, integrity, and persistence. The applicants who did not include any of those three character strengths in their top ranks all failed to complete the selection process. It was also found that the successful and unsuccessful applicants did not differ on physical assessments and a written test.

Doty and Sowden (2009) have argued the importance of integrating the development of character in all ongoing training of soldiers in the U.S. Army. They found that freestanding classes in ethics are ineffective. They also encourage the moral development of soldiers to enhance military results. This is nothing new. In the USMC magazine "The Gazette" from June 1919, the basic principles of morality are laid out: respect, confidence, contentment, harmony and pride. These traits were designated as the foundation of all morality (Jenkins 1919). The development of character was seen as the 
foundation of high morale. Intelligence, combined with character and commitment, has proven successful in the selection of the Special Forces units (Boe 2011, Boe et al. 2011). The NMA aims to develop both intellect and character in its cadets, and regards these as the key characteristics of officer competency. However, systematic research has not yet determined what specific character traits are most important for the Norwegian military army officers to succeed, and hence what character strengths the NMA should strive to develop in their cadets. The NMA, therefore, has decided to launch a research and development project with the purpose of examining character itself, what specific character strengths are most vital to succeed as a military officer, and if and how these character strengths can be developed in cadets at the NMA. An additional aim in this the research project is to investigate whether using character strengths as a selection criterion will aid in selecting the most suitable cadets for entry into the NMA (Boe 2014).

\section{Character versus Personality}

One of the aims of the education at the NMA is to ensure that the officers have what it takes to face challenging and demanding situations while leading others (Boe et al. 2014). Because of the current conflict pattern with contributions to international military operation, it is important for the NMA to ensure that graduating officers are equipped with skills and abilities to face and cope with these types of situations. Research conducted at the NMA has postulated that the officers (referred to as cadets while being students at the NMA) should therefore have sufficient subject matter expertise, social proficiency, and personal foundation so that they can exercise leadership also in this type of situations (Boe 2015a, 2015b, 2015c, 2014, 2013). In a conceptual description of officer development at the NMA it is stated that this will demand a solid character (Boe et al. 2014).

One way to describe a character is that character can be seen as a pattern of qualities that an individual possess. This pattern is unique and distinctly different from other people. This is especially in relation to moral and to mental qualities. One description of personality is that it is a set of qualities that makes an individual unique. Thus, personality may be seen as generally associated with the outer appearance and behaviour of an individual.

Epstein and O'Brien (1985) have found strong evidence that personality traits were potent predictors for behavior if the behavior in question was aggregated over many occasions. However, personality traits were on the other hand found to be poor predictors for single behavioral acts. Epstein and O'Brien postulated that single behavioral acts tended to be both low in reliability and low in generality. They also stated that "given the low reliability of single acts, nothing can be expected to predict them well" (ibid: 532).

A person can express his or her values through one's character. A person's character serves an important role in several aspects of a person's life. Examples of such aspects are leadership, achievement, and adaptability (Matthews et al. 2006, Gayton and Kehoe 2015a, Picano and Roland 2012). 
Furthermore, individual character strengths have proved to be able to predict success when it comes to the selection of personnel into so-called high-risk organizations (Matthews 2008).

A recent study investigating character strengths at work revealed that curiosity, vitality, hope, gratitude, and spirituality were associated with work satisfaction. This was found across different occupations (Peterson et al. 2010). In another study, specifically vitality was found to be associated both with greater life and work satisfaction (Peterson et al. 2009).

Character strengths can be seen as multidimensional, and they are constructed from several positive traits. These positive traits can be found in a person's thinking, and in a person's emotions and behaviours (Park and Peterson 2008). Peterson and Seligman (2004) have acknowledged that there are some clear theoretical correspondences between character strengths and personality traits, as reflected in the Big Five personality dimensions. As an example, the appreciation of beauty, curiosity, and love of learning was found to be conceptually related to openness. Teamwork includes characteristics related to agreeableness; persistence and self-regulation reflect qualities included in conscientiousness; leadership thus includes attributes that were previously associated with extroversion; and hope was related to certain aspects of emotional balance (Peterson and Seligman 2004). Despite these conceptual links, only one study based on a small sample of 123 undergraduate Australian students has empirically examined associations between the VIA-IS and the five personality traits (Macdonald et al. 2008). Only the results of the stepwise regression analyses was reported in this study, with the five personality traits and social desirability as predictor variables and the character strength scores as criterion variables. Today one has not found an empirical report of associations between the Big Five personality traits and specific character strengths (Littman-Ovadia and Lavy 2012). This may be seen as evidence that character strengths are something different from personality traits.

\section{Character Strengths}

In 2004, Peterson and Seligman developed a classification of six virtues and 24 character strengths (see Table 1) ubiquitously recognized and valued across cultures. Research on their classification system has flourished over the past ten years (see Niemiec 2013, for an overview of the research). The six virtues, wisdom and knowledge, courage, humanity, justice, temperance, and transcendence, each have a corresponding set of character strengths, which serve as psychological ingredients or pathways to these virtues. 
Table 1. An Overview of the Classification of Virtues and Character Strengths, based on Niemiec (2013) and Peterson and Seligman (2004)

\begin{tabular}{|c|}
\hline $\begin{array}{l}\text { Wisdom and knowledge } \\
\text { This virtue includes five cognitive strengths related to the acquisition and use of } \\
\text { knowledge }\end{array}$ \\
\hline Creativity [originality, adaptivity, ingenuity] \\
\hline Curiosity [interest, novelty-seeking, exploration, openness to experience] \\
\hline Open-mindedness [judgment, critical thinking, thinking things through] \\
\hline Love of learning [mastering new skills and topics, systematically adding to knowledge] \\
\hline Perspective [wisdom, providing wise counsel, taking the big picture view] \\
\hline Courage \\
\hline $\begin{array}{l}\text { This virtue includes four emotional strengths that are involved in the exercise of } \\
\text { one's will in order to accomplish goals when facing external or internal opposition }\end{array}$ \\
\hline Bravery [valor, not shrinking from fear, speaking up for what's right] \\
\hline Persistence [perseverance, industriousness, finishing what one starts] \\
\hline $\begin{array}{l}\text { Integrity [authenticity, honesty, speaking the truth, presenting oneself and acting in a genuine } \\
\text { and sincere way] }\end{array}$ \\
\hline Vitality [zest, enthusiasm, vigor, energy, feeling alive and activated] \\
\hline Humanity \\
\hline $\begin{array}{l}\text { This virtue includes three interpersonal strengths that deals with tending to and } \\
\text { becoming friendly with others }\end{array}$ \\
\hline Love [valuing close relations with others, both loving and being loved, being close to people] \\
\hline Kindness [generosity, nurturance, care, compassion, altruistic love, niceness, helping others] \\
\hline Social intelligence [emotional intelligence, being aware of the motives/feelings of self/others] \\
\hline Justice \\
\hline This virtue includes three civic strengths that sustains a healthy community life \\
\hline $\begin{array}{l}\text { Teamwork [citizenship, social responsibility, loyalty, doing one's share, working well as a } \\
\text { team member] }\end{array}$ \\
\hline $\begin{array}{l}\text { Fairness [just, to treat people the same, in accordance with the notions of fairness and justice, } \\
\text { and not letting your own feelings bias your decisions about others] }\end{array}$ \\
\hline $\begin{array}{l}\text { Leadership [to organize group activities, to encourage a group to get on with things at the same } \\
\text { time as one maintain good relations within the group] }\end{array}$ \\
\hline Temperance \\
\hline This virtue includes four strengths that protects you against excess \\
\hline $\begin{array}{l}\text { Forgiveness and mercy [accepting the shortcomings of others, to give people a second chance, } \\
\text { not being vengeful] }\end{array}$ \\
\hline $\begin{array}{l}\text { Humility/Modesty [letting your accomplishments speak for themselves, not thinking that you } \\
\text { are more special than you are] }\end{array}$ \\
\hline $\begin{array}{l}\text { Prudence [careful, cautious, not taking undue risks, not saying or doing things that might later } \\
\text { be regretted] }\end{array}$ \\
\hline Self-regulation [self-control, discipline, controlling one's appetites, impulses and emotions] \\
\hline Transcendence \\
\hline $\begin{array}{l}\text { This virtue includes five strengths that strengthens a connection with a larger } \\
\text { universe and provide meaning }\end{array}$ \\
\hline $\begin{array}{l}\text { Appreciation of beauty and excellence [awe, wonder, elevation, noticing and appreciating } \\
\text { beauty, excellence and/or skilled performance in various domains of life] }\end{array}$ \\
\hline Gratitude [being aware and thankful for the good things that happen, feeling blessed] \\
\hline Hope [optimism, future-mindedness, future orientation, believing that a good future is possible] \\
\hline Humor [playfulness, liking to laugh and tease, bringing smiles to others, light-heartedness] \\
\hline $\begin{array}{l}\text { Spirituality [religiousness, faith, to have coherent beliefs revolving around the higher purpose } \\
\text { and the meaning of the universe] }\end{array}$ \\
\hline
\end{tabular}


In addition, each character strength needs to meet most of the following ten criteria: "fulfilling, morally valued, does not diminish others, has nonfelicitous opposites, trait-like, distinctive from other strengths, have paragons who exemplify it, has prodigies, selective absence of it in some situations, and has institutions/rituals to celebrate or express it" (Niemiec 2013: 12).

Based upon the abovementioned theoretical perspectives and empirical findings, we ended up with two aims for the present study. The first aim was the following research question: Which character strengths do experienced military officers consider most important? A second aim was to investigate any degree of consistency between the character strengths chosen in the present study and in our previous studies (Boe and Bang n.d. a, n.d. b , Boe et al. 2015 b , 2015c). A high level of consistency would thus indicate that older and more experienced officers serving in different branches of the Norwegian Armed Forces chose the same character strengths as important as junior officers (Boe and Bang, n.d. a).

\section{Method}

Twenty-one experienced military officers participated in the study. The participants took part in a six months basic officer educational course at the NMA. The participants will normally serve as staff officers after graduation from the course. The course is a prerequisite if an officer wants to be able to work as a commissioned officer in the Norwegian Armed Forces upon graduation. Military ranks ranged from Lieutenant to Major and the participants had an average of 10.3 years ( $\mathrm{SD}=6.9$ years) of active service in the Norwegian Armed Forces before attending an officer qualifying course at the NMA. They were between 28 to 48 years old at the time of participating in the study.

\section{Materials}

Participants were given a paper version questionnaire based upon Peterson and Seligmans (2004) 24 character strengths. The questionnaire was written in Norwegian (Bang 2014). A short definition of each of the 24 character strengths was included in the questionnaire directly after the name of the character strength itself. For instance, the character strength integrity had the following definition: Being genuine, honest and sincere in everything one says and does, take responsibility for your own feelings and actions, dislike to imagine (author's translation). The character strength social intelligence had a short definition: To read and understand your own and others motives and feelings, knowing what one should do to fit into different social situations, knowing what makes others thrive (authors translation). The purpose of including these short definitions in the questionnaire was to make sure that the participants understood what each character's strength is, before judging its importance for military officers. 


\section{Procedure}

Participants filled out the paper version questionnaire during a classroom discussion at the NMA on leadership. They were first informed about the purpose of the study. They were further informed that would be anonymous, and that the data would only be used in order to look at the participants as a group, and that only the authors would have access to the data. Participants were given an individual code, and then asked to put this code on their questionnaire at the start of filling it out. Participants were then asked to read the introduction part of the questionnaire. They were then requested to fill out their rank, and then which unit they belonged to in the Norwegian Armed Forces before attending the course at the NMA. They were then requested to indicate the number of years they had been working in the Norwegian Armed Forces. After that, they were asked to rate the importance of each of the 24 character strengths for a military leader on a scale ranging from 1 ("not important") to 5 ("very important"). The higher score given to specific character strengths, the more important this character strength was considered to be. When all the participants had finished filling in the questionnaire, the questionnaires were collected by an NMA instructor and then handed to one of the authors of this article for data processing.

\section{Analyses}

The answers that the participants gave to the questionnaires were analyzed using IBM SPSS 23.0. In order to differentiate between important and less important character strengths a cut-off point of 4.00 was used in the analyses. A score higher than 4.00 meant that the character strength would be "important" on a scale ranging from 1 (not important) to 5 (very important).

\section{Results}

Table 2 below gives an overview of the answers the participants gave to each of the 24 character strengths. Table 2 reveals that the participants gave 13 of the 24 character strengths a score higher than 4.00. The most important character strength was leadership, followed by teamwork, open-mindedness, integrity, persistence, bravery, curiosity, love of learning, social intelligence, fairness, perspective, creativity, and self-regulation. The scores in table 2 corroborate our previous finding in that, 12 of the same 13 character strengths were chosen to be important by another group of military officers (Boe et al. 2015a). In addition, Boe et al. $(2015 b, 2015 c)$ found that 12 of the same character strengths were chosen as important by experienced military officers. In these two studies, curiosity was not chosen as an important character strength. 
Table 2. Mean Values and Standard Deviations (SD) Given to the 24 Character Strengths by the Military Officers $(n=21)$

\begin{tabular}{|l|l|l|l|}
\hline Core Virtue & Character Strengths & Mean* $^{*}$ & SD \\
\hline Justice & 1. Leadership & 4.86 & 0.36 \\
\hline Justice & 2. Teamwork & 4.81 & 0.40 \\
\hline Wisdom & 3. Open-mindedness & 4.81 & 0.40 \\
\hline Courage & 4. Integrity & 4.76 & 0.44 \\
\hline Courage & 5. Persistence & 4.71 & 0.72 \\
\hline Courage & 6. Bravery & 4.62 & 0.59 \\
\hline Wisdom & 7. Curiosity & 4.58 & 0.50 \\
\hline Wisdom & 8. Love of learning & 4.43 & 0.51 \\
\hline Humanity & 9. Social intelligence & 4.43 & 0.60 \\
\hline Justice & 10. Fairness & 4.42 & 0.81 \\
\hline Wisdom & 11. Perspective & 4.29 & 0.72 \\
\hline Wisdom & 12. Creativity & 4.14 & 0.36 \\
\hline Temperance & 13. Self-regulation & 4.00 & 0.63 \\
\hline Temperance & 14. Prudence & 3.90 & 0.89 \\
\hline Humanity & 15. Kindness & 3.90 & 0.62 \\
\hline Temperance & 16. Forgiveness and mercy & 3.90 & 0.63 \\
\hline Transcendence & 17. Hope & 3.86 & 0.73 \\
\hline Temperance & 18. Humility/Modesty & 3.85 & 0.73 \\
\hline Courage & 19. Vitality & 3.76 & 0.54 \\
\hline Transcendence & 20. Humor & 3.71 & 0.78 \\
\hline Humanity & 21. Love & 3.57 & 0.93 \\
\hline Transcendence & 22. Gratitude & 3.57 & 0.82 \\
\hline Transcendence & 23. Appreciation of beauty & 2.76 & 0.94 \\
\hline Transcendence & 24. Spirituality & 1.90 & 1.22 \\
\hline
\end{tabular}

* Scale ranging from 1 (not important) to 5 (very important).

As can be seen in Table 2, the 13 chosen character strengths are mainly related to the core virtues justice, wisdom, and courage. One of the character strengths are related to the core virtue humanity, whereas no character strengths were chosen as important for military officers from the core virtue transcendence. One character strength, self-regulation, was chosen from the virtue temperance.

In the studies by Boe et al. (2015a, 2015b, 2015c) self-regulation was among the 12 chosen character strength whereas curiosity was not chosen as one of the 12 important character strengths. Our results from the present study are consistent with a fourth study showing that 12 of the same character strengths as in the three previous mentioned conducted studies were chosen as important by military officers (Boe and Bang n.d. a). In this study, curiosity was again not chosen as important character strength. In a larger fifth study with 100 participants Boe \& Bang (in progress) again found that the same 12 character strengths was chosen as the most important as in the three studies by Boe et al. (2015a, 2015b, 2015c). This lends credibility to the existence of a consistent perception of which 12 character strengths that are considered the most important for military officers. In the study by Boe and Bang (n.d. a), the participants were 100 junior officers enrolled at the NMA. They were taking part in a three-year bachelor's program that would lead them to becoming lieutenants in the Norwegian Army after graduation. Their age was between 
21-28 years and as a group they were significantly younger than the participants in the present study. The participants in the present study came from different branches of the Norwegian Armed Forces, and as such, they were very different from the junior officers from the Norwegian Army in Boe and Bang's study (n.d. a). Despite this, the results from the present study and for the mentioned study conducted by Boe and Bang (n.d. a) yielded almost identical results. This lends credibility to our claim that there exists a group of 12 character strengths that are the most important for military officers.

Sweeney et al. (2009) have also reported that military leaders with humor as a character strength could predict their followers trust. Our results did not correlate with this finding, as humor was not seen as very important by our participants. According to Sweeney et al. followers with the character strength perspective earned their leaders' trust. Here our results corroborate better with Sweeney et al. (2009) as the character strength perspective was found by our participants to be important.

\section{Conclusion}

The study aimed at investigating which character strengths that were seen as most important for experienced Norwegian military officers. A second aim was to investigate if there was consistency between the character strengths chosen in the present study and in our previous studies (Boe and Bang n.d. a, n.d. b, Boe et al. 2015b, 2015c). The research question posed in this study was: Which character strengths do experienced military officers consider most important? A second aim was to investigate any degree of consistency between the character strengths chosen in the present study and in our previous studies (Boe and Bang n.d. a, n.d. b, Boe et al. 2015b, 2015c).

The results from the present study indicate a very strong consistency between our findings and the findings in two previous studies conducted at the NMA existed (Boe et al. 2015b, 2015c). In these two previous studies, 12 of the same 13 character strengths were the most important ones for military officers. In addition, two other conducted studies revealed almost the same pattern, as 12 out of the same character strengths also in these studies were the same as in the present study. At this point, we think that there is some truth in our claim that 12 of the character strengths that military officers consider to be important for military officers exist. However, caution needs to be asserted, as the number of participants in the present study, as well as in our previous two studies (Boe et al. 2015b, 2015c) is very low. This indicates that the external validity of our findings will be limited. However, a forthcoming study (Boe and Bang n.d. a) thus validate our finding in this study. In addition, a larger forthcoming study, also by Boe and Bang (n.d. b) adds credibility to our findings in the present study. More research is needed in the future on the subject of which character strengths are the most important for military officers before a clear and valid conclusion can be drawn. Nevertheless, at this point, we feel that we can state that several character strengths are ranked as the most 
important for Norwegian military officers. This thus indicates a presence of the big 12 when referring to important character strengths for military officers.

\section{Acknowledgments}

This research work was supported by the NMA. The views that are expressed in this article are the authors and the views do not represent an official position held by the Norwegian Army. The authors wish to thank senior lecturer Merete Ruud at the NMA for valuable help with the language of this work

\section{References}

Bang H (2014) Definisjoner og beskrivelser av 24 karakterstyrker, klassifisert under 6 dyder [Definitions and descriptions of the 24 character strengths, classified under 6 virtues]. Working paper. The Norwegian Military Academy.

Barrick MR, Mount MK (1991) The Big Five personality dimensions and job performance: a meta-analysis. Personnel Psychology 44: 1-26..

Biswas-Diener R, Kashdan TB, Minhas G (2011) A dynamic approach to psychological strength development and intervention. Journal of Positive Psychology 6(2): 106-118.

Boe O (2016) Building Resilience: The Role of Character Strengths in the Selection and Education of Military Leaders. International Journal of Emergency Mental Health and Human Resilience 17(4): 714-716.

Boe O (2015a) Developing leadership skills in Norwegian military officers: Leadership proficiencies contributing to character development and officer competency. Procedia-Social and Behavioral Sciences 186: 288-292.

Boe O (2015b) Character in military leaders, officer competency and meeting the unforeseen. Procedia-Social and Behavioral Sciences 190: 497-501.

Boe O (2015c) Karaktertrekk hos ledere og møte med det uforutsette [Character strengths and meeting the unforeseen]. In Pedagogikk for det uforutsette, G-E Torgersen (ed.), .196-210. Bergen: Fagbokforlaget.

Boe O (2014) Prosjektbeskrivelse for KS FoU-prosjekt: Karakter hos militcere offiserer [Project description for NMAs research and development project: Character in military officers]. Research project applied for to the Norwegian Military Academy, 1-39.

Boe O (2013) Leadership development in Norwegian junior military officers: A conceptual framework of building mission-solving competency. Proceedings of the $16^{\text {th }}$ International Military Mental Health Conference (16IMMHC).

Boe O (2011) How to find leaders that will be able to face and solve problematic decisions in an operational context? Proceedings of the $13^{\text {th }}$ International Military Health Conference (13IMMHC), 35-42.

Boe O, Bang H (n.d. a) Assessing the correlation between character strengths and mental toughness in military officers. Procedia-Social and Behavioral Sciences (forthcoming).

Boe O, Bang H (n.d.b) Risk seeking and character strengths in military officers. The Norwegian Military Academy. [in progress] 
Boe O, Bang H, Nilsen FA (2015a) The development of an observational instrument in order to measure character strengths. Procedia-Social and Behavioral Sciences 197: 1126-1133.

Boe O, Bang H, Nilsen FA (2015b) Selecting the most relevant character strengths for Norwegian Army officers: An educational tool. Procedia-Social and Behavioral Sciences 197: 801-809.

Boe O, Bang H, Nilsen FA (2015c) Experienced military officer's perception of important character strengths. Procedia-Social and Behavioral Sciences 190, 339-345.

Boe O, Eldal L, Hjortmo H, Jensen AL, Holth T, Kjørstad O, Nilsen F (2014) Offisersutvikling: NMA konsept for lederutvikling [Officer development: NMAs concept of leadership development]. Oslo: Norwegian Military Academy.

Boe O, Woolley K, Durkin J (2011) Choosing the elite: Examples of the use of recruitment, assessment, and selection programs in Law Enforcement Tactical Teams and Special Forces. In Leading in Dangerous Contexts, P Sweeney, M Matthews, P Lester (eds), 333-349. Naval Institute Press.

Doty J, Sowden W (2009) Competency vs. character? It must be both!. Military Review 89(6): 69-76.

Elsass WP, Fiedler E, Skop B, Hill H (2001) Susceptibility to maladaptive responses to stress in basic military training based on variants of temperament and character. Military Medicine 166: 884-888.

Epstein S, O'Brien EJ (1985) The person-situation debate in historical and current perspective. Psychological Bulletin 98: 513-537.

Furnham A, Fudge C (2008) The Five Factor model of personality and sales performance. Journal of Individual Differences 29(1): 2008, 11-16.

Forsvaret (2012) FSJ grunnsyn på ledelse i Forsvaret [The Norwegian armed forces chief of defence basic view of leadership in the armed forces]. Norway: Norwegian Armed Forces Defence Staff.

Gayton SD, Kehoe EJ (2015a) A prospective study of character strengths as predictors of selection into the Australian Army Special Forces. Military Medicine 180(2): 151-157.

Gayton SD, Kehoe EJ (2015b) Character Strengths and Hardiness of Australian Army Special Forces Applicants. Military Medicine 180( 8): 857-862.

Jenkins EA (1919) Character-building the basis for a high morale. Marine Corps Gazette 5(1).

Kolditz T A (2010) In extremis leadership: leading as if your life depended on it. San Francisco, USA: Jossey Bass.

Littman-Ovadia H, Lavy S (2012) Character strengths in Israel: Hebrew adaptation of the VIA Inventory of Strengths. European Journal of Psychological Assessment 28(1): 41-50.

Macdonald C, Bore M, Munro D (2008) Values in Action Scale and the Big 5: An empirical indication of structure. Journal of Research in Personality 42: 787799.

Matthews MD (2008) Positive psychology: Adaptation, leadership, and performance in exceptional circumstances. In Performance under Stress, PA Hancock, JL Szalma (eds), 163-180. Aldershot, England: Ashgate.

Matthews MD, Eid J, Johnsen BH, Boe O (2011) A comparison of expert ratings and self-assessments of situation awareness during a combat fatigue course. Military Psychology 23(2): 125-136. 
Matthews MD, Eid J, Kelly D, Bailey JK, Peterson C (2006) Character strengths and virtues of developing military leaders: An international comparison. Military Psychology 18: 557-568.

Matthews MD, Martinez SG, Eid J, Johnsen BH, Boe O (2007) A comparison of observer and incumbent ratings of situation awareness. Human Factors and Ergonomics Society Annual Meeting Proceedings, Cognitive Engineering and Decision Making, 548-552(5).

Niemiec R (2013) VIA character strengths: Research and practice (The First 10 Years). In Well-Being and Cultures: Perspectives from Positive Psychology, $\mathrm{HH}$ Knoop, A Delle Fave (eds), ch 2. Dordrecht: Springer.

Park N, Peterson C (2008) Positive psychology and character strengths: Application to strengths-based school counseling. Professional School Counseling 12: 85-92.

Peterson C, Park N, Hall N, Seligman ME P (2009) Zest and work. Journal of Organizational Behavior 30: 161-172.

Peterson C, Seligman EP (2004) Character strengths and virtues: A handbook and classification. New York: Oxford University Press.

Peterson C, Stephens JP, Park N, Lee F, Seligman ME P (2010) Strengths of character and work. In Handbook of Positive Psychology and Work, PA Linley, S Harrington, N Page (eds), 221-231. New York: Oxford University Press.

Picano JJ, Roland RR (2012) Assessing psychological suitability for high-risk military jobs. In The Oxford Handbook of Military Psychology, JH Laurence, MD Matthews (eds.), 148-157. New York: Oxford University Press.

Picano JJ, Roland RR, Rollins KD, Williams TJ (2002) Development and validation of a sentence completion test measure of defensive responding in military personnel assessed for non-routine missions. Military Psychology 14: 279-98.

Picano JJ, Williams TJ, Roland RR (2006) Assessment and Selection of High-Risk Operational Personnel. In Military Psychology: Clinical and operational applications, CH Kennedy, EA Zillmer (eds), 353-370. New York: Guilford.

Ployhart RE, Lim BC, Chan KY (2001) Exploring relations between typical and maximum performance ratings and the five factor model of personality. Personnel Psychology 54: 809-843.

Schmidt F L, Hunter JE (1998) The validity and utility of selection methods in personnel psychology: practical and theoretical implications of 85 years of research findings. Psychological Bulletin 124: 262-74.

Sosik JJ, Megerian LE (1999) Understanding leader emotional intelligence and performance: The role of self-other agreement on transformational leadership perceptions. Group and Organization Management 24: 367-390.

Sweeney P, Hannah ST, Park N, Peterson C, Matthews M, Brazil D (2009) Character strengths, adaptation, and trust. Paper presented at the International Positive Psychology Association conference on June 19, 2009.

Torgersen GE, Steiro TJ, Sæverot H (2013) Strategic education management: Outlines for a didactic planning model for exercises and training of the unexpected in high risk organizations. Proceedings of the $22^{\text {nd }}$ Society for Risk Analysis Europe (SRA E) Conference. 
